\title{
Pengaruh Iklim Kerja dan Kualitas Mengajar Guru Terhadap Prestasi Belajar Siswa
}

\author{
Kristianus J. Tute ${ }^{1}$, Lely Suryani ${ }^{2}$, Ariswan Usman AJe ${ }^{3}$ \\ Universitas Flores, Nusa Tenggara Timur, Indonesia ${ }^{1,2,3}$ \\ E-mail : jtutekristian@gmail.com ${ }^{1}$ lelypane@gmail.com ${ }^{2} \underline{\text { ariswanusman @ gmail.com }}^{3}$
}

\begin{abstract}
Abstrak
Permasalahan dalam penelitian ini adalah bahwa tidak semua sekolah di Kecamatan Ende Utara memiliki prestasi belajar yang semuanya baik. Hal ini disebabkan iklim kerja dan kualitas mengajar guru yang berbeda-beda. Metode dalam penelitian ini adalah metode survei dengan pendekatan kuantitatif, sampel diambil secara random dengan 107 guru dan siswa/i 107. Teknik pengumpulan data berupa instrumen dalam bentuk angket skala likert dan nilai siswa/i SMA/K semester 4 dan 5 tahun ajaran 2017/2018, teknik analisis data korelasi pearson product moment dan regresi berganda. Variabel dalam penelitian ini yaitu variabel bebas X1 iklim organisasi dan variabel bebas ke dua X2 kualitas mengajar guru dan variabel terikat adalah prestasi belajar siswa di kecamatan Ende Utara. Hasil analisis dalam penelitian ini menunjukan bahwa iklim organisasi sekolah (X1) berpengaruh secara positif sebesar 0.754 ( $75.4 \%$ ) terhadap prestasi belajar (Y) dan kualitas mengajar guru (X2) juga berpengaruh secara signifikan sebesar $0.774(77.4 \%)$ terhadap prestasi belajar Y. Secara bersama-sama prestasi belajar siswa di sekolah di pengaruhi oleh iklim organisasi dan kualitas mengajar guru sebesar 0.702 ( $70.2 \%$ ) dan sisanya $29.8 \%$ yang bukan menjadi fokus dalam penelitian ini. Saran: (1) bagi para kepala sekolah, guru-guru dan siswa/i hendaknya menjalin hubungan yang baik antar individu sehingga tercipta iklim kerja yang harmonis, (2) meningkatkan kualitas mengajar guru melalui pendidikan dan pelatihan, kursus-kursus dan seminar, (3) kepala sekolah memberikan kesempatan kepada guru-guru untuk melanjutkan pendidikan ke jenjang yang lebih tinggi.
\end{abstract}

Kata kunci : iklim kerja sekolah, kualitas mengajar guru dan prestasi belajar

\section{Abstract}

The problem in the research is that not all school in the Ende North District of Ende Regency have learning achievementsthat are all good. This caused by the work climate and the quality of teaching different teachers. Method in this research is survey method with quantitative approach of sample taken at random with 107 teacher and 107 student. Data collection techniques are in the form of questionnaire likert scale and grades of students SMA/K semester 4 and 5 academic year 2017/2018, data analysis techniques pearson product moment and multiple regression. Variables in this research are independent variable X1 organizational climate and independent variable to two X2 teacher teaching quality and dependent variable is student achievement in sub district of North Ende.The result of the analysis in this study showed that the climate of school organization (X1) had a positive effect of 0.754 (75.4\%) on the achievement of learning $(Y)$ and the teaching quality of teachers (X2) also significantly influenced by 0.774 (77.4\%) on the learning achievement $(Y)$. Together learning achievements students at school are influenced by the organizational climate and teachers' qualities of 0.702 (70.2\%) and the remaining $29.8 \%$ are not the focus of this research. Suggestions: (1) for principals, teachers and students, (2) improving the quality of teachers' teaching through education and training, courses and seminars, (3) principals provide opportunities for teachers to continue their education to a more advanced level high.

Keywords: school working climate, teaching quality teachers and student learning achievement

Copyright (c) 2020 Kristianus J. Tute, Lely Suryani, Ariswan Usman AJe

$\triangle$ Corresponding author

Address : Universitas Flores

Email : jtutekristian@gmail.com

Phone : 082144901961

DOI: https://doi.org/10.31004/basicedu.v4i4.554
ISSN 2580-3735 (Media Cetak)

ISSN 2580-1147 (Media Online) 
1327 Pengaruh Iklim Kerja dan Kualitas Mengajar Guru Terhadap Prestasi Belajar Siswa - Kristianus J. Tute, Lely Suryani, Ariswan Usman AJe

DOI: https://doi.org/10.31004/basicedu.v4i4.554

\section{PENDAHULUAN}

Sekolah merupakan lembaga organisasi pendidikan yang menjadi tempat berlangsungnya proses pembelajaran yang bertujuan untuk mencapai tujuan pembangunan nasional. Sebuah organisasi dikatakan berhasil apabila organisasi tersebut memiliki sumber daya manusia yang berkualitas, begitu pula halnya di sekolah. Keberhasilan visi, misi dan tujuan di sekolah tergantung pada sumber daya manusia yang ada di sekolah tersebut, seperti kepala sekolah, guruguru, siswa- siswi, pegawai tata usaha dan tenaga kependidikan yang ada di sekolah tersebut.

Supardi, (2013) mengatakan bahwa sekolah memiliki iklim kondusif apabila kepala sekolah dan guru memiliki etos kerja dan peserta didik memiliki etos belajar, sedikit pelanggaran disiplin dan tata tertib baik sekolah maupun pesreta didik. Dengan demikian, iklim sekolah merupakan keadaan sekitar sekolah suasana sunyi dan nyaman yang sesuai dan kondusif untuk pembelajaran yang dapat meningkatkan prestasi akademik. Iklim kerja yang baik adalah iklim kerja yang benar-benar sesuai dan dapat mendukung kelancaran serta kelangsungan proses pembelajaran yang dilakukan oleh guru.

Guru merupakan salah satu faktor yang dapat mempengaruhi proses pembelajaran selain faktor lingkungan belajar dan siswa. Menurut Sanjaya, (2014) untuk meningkatkan kualitas pendidikan dapat dimulai dengan menganalisis setiap komponen yang dapat membentuk dan mempengaruhi proses pembelajaran. Dan salah satu komponen itu adalah guru. Guru adalah orang yang yang memiliki ilmu, dan dengan ilmu yang dimilikinya guru menanamkan kepada orang lain.

Menurut Karwati dan Priansa, (2014) pengertian guru dalam konteks pendidikan terkait dengan profesi yang diembannya sebagai pendidik dan pengajar bagi pesrta didik yang ada diberbagai jenjang pendidikan. Dengan pengertian diatas dapat kita katakan bahwa tugas utama guru adalah mengajar. Hal ini sejalan dengan undang-undang no 14 tahun 2005 yang mengatakan bahwa guru adalah pendidik profesional dengan tugas utamanya adalah mendidik mengajar, membimbing, mengarahkan, melatih, menilai dan mengevaluasi peserta didik pada pendidikan anak usia dini jalur pendidikan formal, pendidikan dasar dan pendidikan menengah.

Keprofesionalan seorang guru menunjukan seberapa besar kualitas yang dimilikinya. Syah, (2003:229) menyatakan bahwa "Guru yang berkualitas adalah guru yang berkompetensi, yang berkemampuan untuk melaksanakan kewajibankewajibannya secara bertanggung jawab dan layak". Dengan demikikian dapat dikatakan bahwa seorang guru yang berkualitas mesti memiliki kompetensi yang memadai.

(Depdiknas, 2007) membagi kompetensi guru atas empat dimensi yaitu: (1) kompetensi pedagogik, (2) kompetensi kepribadian, (3) kompetensi profesional, (4) kompetensi sosial. Dengan empat kompetensi yang dimiliki guru diatas, maka kesempatan untuk memperbaiki prestasi belajar siswa pada khususnya dan perbaikan kualitas pendidikan akan lebih mudah tercapai. Prestasi belajar merupakan hasil yang diperoleh setelah melalui suatu proses 
1328 Pengaruh Iklim Kerja dan Kualitas Mengajar Guru Terhadap Prestasi Belajar Siswa - Kristianus J. Tute, Lely Suryani, Ariswan Usman AJe

DOI: https://doi.org/10.31004/basicedu.v4i4.554

pembelajaran. Dengan pembelajaran yang baik maka harapan akan prestasi belajar yang lebih baik akan lebih besar. Pembelajaran yang baik dapat diberikan apabila guru memiliki kualitas mengajar yang mumpuni. Dengan empat kompetensi tersebut guru diharapkan mampu mengangkat prestasi belajar siswa. Dari uraian diatas dapat kita katakan terdapat hubungan antara iklim kerja guru, kualitas mengajar serta prestasi belajar siswa.

\section{Iklim Kerja}

Wirawan, (2007) iklim kerja adalah persepsi anggota organisasi (secara individual dan kelompok) dan mereka yang secara tetap berhubungan dengan organisasi (misalnya pemasok, konsumen, konsultan, dan kontraktor) mengenai apa yang ada atau terjadi di lingkungan internal organisasi secara rutin, yang mempengaruhi sikap dan perilaku organisasi dan kinerja anggota organisasi yang kemudian menentukan kinerja organisasi.

Menurut Robert G. Owens dalam (Wirawan, 2007) mendefinisikan iklim kerja sebagai “.....study of perception that individuals have of various aspects of the environment in the organization". Iklim kerja dapat didefinisikan sebagai studi persepsi individu mengenai berbagai aspek lingkungan oganisasinya.

James L.Gibson dkk (dalam Oteng, 2009) mendefenisikan iklim kerja sebagai: iklim merupakan satu set perlengkapan dari suatu lingkungan kerja yang dirasakan secara langsung atau tidak langsung oleh karyawan yang bekerja di lingkungan ini dan beranggapan akan menjadi kekuatan utama yang mempengaruhi tingkah laku mereka dalam bekerja.
Berkenaan dengan hal tersebut iklim organisasi diartikan sebagai suatu ciri yang membedakan antara suatu organisasi dengan organisasi lain, karena tiap tiap organisasi memiliki budaya, tradisi dan metode tindakan sendiri yang secara keseluruhan dapat menciptakan iklim kerja di sebuah organisasi tersebut, atau dalam pendapat lain iklim kerja merupakan konsep sistem yang mencerminkan keseluruhan gaya hidup suatu organisasi.

\section{Kualitas Mengajar Guru}

Goetsch and Davis (dalam Raharjo, 2013) memberikan definisi tentang kualitas adalah sebagai berikut "quality is dynamic state associate with product, service, people, process, and environments that metts or exceeds expectations". Kualitas merupakan pernyataan yang dinamis yang terkait dengan produk, pelayanan, orang, proses dan lingkungan yang dapat memenuhi atau melebihi yang diharapkan.

Selanjutnya Ishikawa (dalam Raharjo, 2013) mendefinisikan kualitas sebagai berikut. (a) quality and customer satisfaction are the same things and, (b) quality is a broad concept that goes beyond just product quality to also include the quality of people, processes, and every other aspect of the organization. Artinya kualitas memiliki dua dimensi yaitu: (a) kualitas dan kepuasan pelanggan merupakan hal yang sama, karena bila pelanggan mendapatkan kualitas barang atau jasa, maka akan memperoleh kepuasan, (b) kualitas merupakan konsep yang luas yang bukan hanya kualitas produk, tetapi juga kualitas orang, proses kerja, dan setiap aspek dari organisasi. 
1329 Pengaruh Iklim Kerja dan Kualitas Mengajar Guru Terhadap Prestasi Belajar Siswa - Kristianus J. Tute, Lely Suryani, Ariswan Usman AJe

DOI: https://doi.org/10.31004/basicedu.v4i4.554

Dari pengertian diatas dapat dikatakan bahwa kualitas adalah tingkatan baik buruknya bentuk pelayanan kepada orang lain. Kualitas mencakup setiap aspek dari organisasi, seperti kualitas produk, orang dan proses kerja.

Menurut (Omar, 2013) pengertian mengajar sebagai berikut :

1. Mengajar ialah menyampaikan pengetahuan kepada siswa didik atau murid disekolah

2. Mengajar adalah mewariskan kebudayaan kepada generasi muda melalui lembaga pendidikan sekolah.

3. Mengajar adalah usaha mengorganisasi lingkungan sehingga menciptakan kondisi belajar bagi siswa.

Mnurut Wahab (dalam Susanto, 2016) konsep mengajar sebagai berikut:

1. Mengajar adalah komunikasi antara dua orang atau lebih dimana antara keduanya terdapat saling mempengaruhi melalui pemikiranpemikiran mereka dan belajar sesuatu dari interaksi itu.

2. Mengajar adalah mengisi pikiran siswa dengan berbagai informasi dan pengetahuan tentang fakta untuk kegunaan pada masa akan datang.

3. Mengajar adalah proses dalam mana pelajar, guru, kurikulum dan variabel lainya disusun dengan cara sistematis guna mencapai tujuan yang telah ditetapkan.

Dari pengertian tersebut mengajar adalah proses penyampaian pengetahuan oleh guru kepada siswa, dimana pengetahuan yang disampaikan tersebut disusun secara sistematis guna mencapai tujuan yang telah ditetapkan sebelumnya.
Menurut Mandaru (dalam Maria \& Ungin, 2013) "Studi tentang Kualitas Tenaga Pengajar (Guru) pada SMPN 17 Sendawar Kabupaten Kutai Barat." Jurnal Administrasi Negara. 1 (1). Hlm. 97-108. Kualitas seseorang harus menjadi prioritas dalam upaya mengembangkan sebuah pola pendidikan yang efektif. Kualitas seorang guru ditandai dengan tingkat kecerdasan ketangkasan, dedikasi, dan loyalitas yang tinggi serta iklas dalam memajukan pendidikan mencerdaskan anak didik. Lebih lanjut menurut Maria \& Ungin, (2013) kualitas guru adalah bagian penting dari proses belajar-mengajar yang merupakan tujuan dari suatu organisasi pendidikan. Kualitas seorang guru terhadap mutu pendidikan yaitu kemampuan yang dimiliki oleh seorang guru yang diberikan kepada anak didiknya yang diharapkan mampu meningkatkan kualitas kelulusan, baik dalam kualitas pribadi, moral, pengetahuan mampu kompetensi kerja.

Dengan mengkaitkan antara pengertian kualitas dapat dikatakan bahwa kualitas mengajar guru adalah tingkat kecerdasan dan ketangkasan guru dalam menyampaikan maksud atau pembelajaran kepada siswanya. Alat ukur untuk tingkatan guru yang berkualitas adalah profesionalismenya dalam bekerja. Keprofesionalannya terlihat dari empat kompetensi yang dimiliki seperti seperti kompetensi pedagogik, kompetensi profesional, kompetensi sosial, dan kompetensi kepribadian. Seperti yang dikemukakan Muhibbin,( 2003) menyatakan bahwa "guru yang berkualitas adalah guru yang berkompetensi, yang berkemampuan untuk 
1330 Pengaruh Iklim Kerja dan Kualitas Mengajar Guru Terhadap Prestasi Belajar Siswa - Kristianus J. Tute, Lely Suryani, Ariswan Usman AJe

DOI: https://doi.org/10.31004/basicedu.v4i4.554

melaksanakan kewajiban-kewajibannya secara bertanggung jawab dan layak".

\section{Prestasi Belajar}

Sebelum kita mengetahui pengertian prestasi belajar, kita juga mesti mengetahui pengertian belajar. Menurut Skinner (dalam Dimyati \& Mudjiono, 2006) belajar adalah suatu perilaku. Pada saat orang belajar maka responnya menjadi lebih baik. Sebaliknya bila ia tidak belajar maka responnya menurun. Susanto, (2016) mendefenisikan belajar adalah suatu aktivitas yang dilakukan seseoarang dengan sengaja dalam keadaan sadar untuk memperoleh suatu konsep, pemahaman atau pengetahuan baru sehingga memungkinkan seseorang terjadinya perubahan perilaku yang relatif tetap baik dalam berpikir, merasa, maupun dalam bertindak. Dengan demikian dapat disimpulkan bahwa belajar adalah proses perubahan tingkah laku suatu individu dimulai dengan proses berpikir dan mengambil kesimpulan dari pemikirannya sebagai respon berpikir tersebut.

Menurut kamus besar Bahasa Indonesia prestasi adalah hasil yang telah dicapai (dari yang telah dilakukan, dikerjakan dsb). Djamarah, Syaiful, \& Aswan, (2012) mengatakan bahwa prestasi adalah hasil dari suatu kegiatan yang telah dikerjakan, diciptakan, baik secara individual maupun kelompok. Sedangkan Harahap dkk (dalam Djamarah et al., 2012) memberikan batasan mengenai prestasi adalah penilaian pendidikan tentang perkembangan dan kemajuan murid yang berkenaan dengan penguasaan bahan pengajaran yang disajikan kepada mereka serta nilai-nilai yang terdapat dalam kurikulum.

Menurut Adib \& Santoso, (2016) prestasi belajar adalah suatu usaha atau kegiatan anak untuk menguasai bahan-bahan pelajaran yang diberikan guru di sekolah. Prestasi belajar adalah istilah yang telah dicapai individu sebagai usaha yang dialami secara langsung. Prestasi belajar adalah hasil penilaian pendidik terhadap proses dan hasil belajar siswa yang menggambarkan penguasaan siswa atas materi pelajaran atau perilaku yang relatif menetap sebagai akibat adanya proses belajar yang dialami siswa dalam jangka waktu tertentu.

\section{Hipotesis Penelitian}

Berdasarkan asusimsi diatas maka hipotesis dalam penelitian ini adalah terdapat pengaruh yang signifikan secara simultan antara iklim organisasi dan kualitas mengajar guru terhadap prestasi belajar siswa di Kecamatan Ende Utara Kabupaten Ende NTT.

\section{METODE}

Metode yang digunakan dalam penelitian ini adalah metode survei dengan pendekatan kuantitatif. Metode ini digunakan kerena peneliti ingin mengetahui hasil iklim kerja sekolah dan kualitas mengajar guru apakah berpengaruh pada prestasi belajar siswa di Kecamatan Ende Utara Kabupaten Ende NTT.

\section{Populasi dan Sampel Penelitian}

Populasi adalah wilayah generalisasi yang terdiri atas objek atau subjek yang mempunyai kualitas dan karakteristik tertentu yang ditetapkan oleh peneliti yang dipelajari dan kemudian ditarik kesimpulannya. Jadi populasi bukan hanya orang 
1331 Pengaruh Iklim Kerja dan Kualitas Mengajar Guru Terhadap Prestasi Belajar Siswa - Kristianus J. Tute, Lely Suryani, Ariswan Usman AJe

DOI: https://doi.org/10.31004/basicedu.v4i4.554

tetapi juga objek dan benda-benda. Adapun sekolah Menegah Atas di Kecamatan Ende Utara.

\section{Sampel}

Sampel adalah bagian dari populasi, karena keterbatasan dana, waktu, tenaga maka peneliti dapat menggunakan 4 sampel SMA/K yang akan diambil secara acak dari populasi di Kecamatan Ende Utara yang terdiri dari 107 orang guru-guru dari populasi 160 dan 107 siswa/i dari populasi 350 orang.

\section{Rancangan Penelitian}

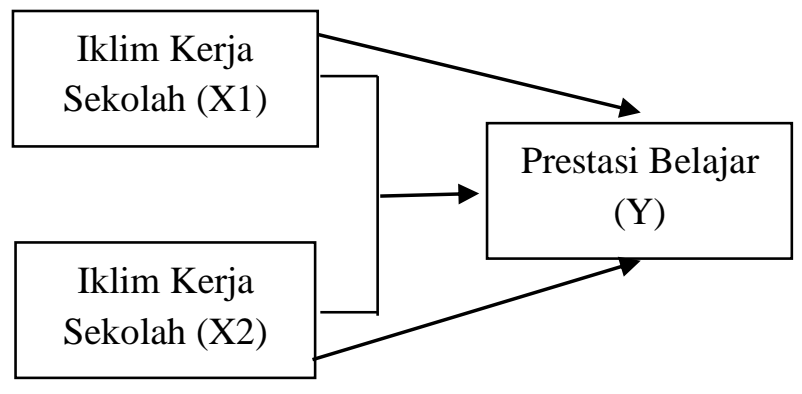

Gambar 1. Pengaruh X1 dan X2 Terhadap Y

\section{Teknik Pengumpulan Data}

Teknik pengumpulan data yang pertama menggunakan angket untuk mengukur iklim organisasi sekolah dan kualitas mengajar guru mengenai pendapat dan persepsi seseorang atau kelompok orang tentang fenomena sosial dan kedua nilai siswa/i semester 4 dan 5 tahun akademik 2017/2018. Instrumen penelitian yang digunakan skala likert dalam bentuk angket.

\section{Teknik Analisis Data}

Metode penelitian adalah metode survei dengan pendekatan kuantitatif. Instrumen berupa angket dengan skala likert, teknik analisis yang digunakan adalah korelasi product moment dan regresi berganda.

\section{HASIL DAN PEMBAHASAN}

Metode dalam penelitian ini adalah metode survei dengan pendekatan kuantitatif, sampel diambil secara random dengan 107 guru dan siswa/i 107. Teknik pengumpulan data berupa instrumen dalam bentuk angket skala likert. Teknik analisis data korelasi pearson product moment dan regresi berganda. Variabel dalam penelitian ini yaitu variabel bebas X1 iklim organisasi dan variabel bebas ke dua X2 kualitas mengajar guru dan variabel terikat adalah prestasi belajar siswa di Kecamatan Ende Utara.

Tabel 1 Deskriptive Statistics

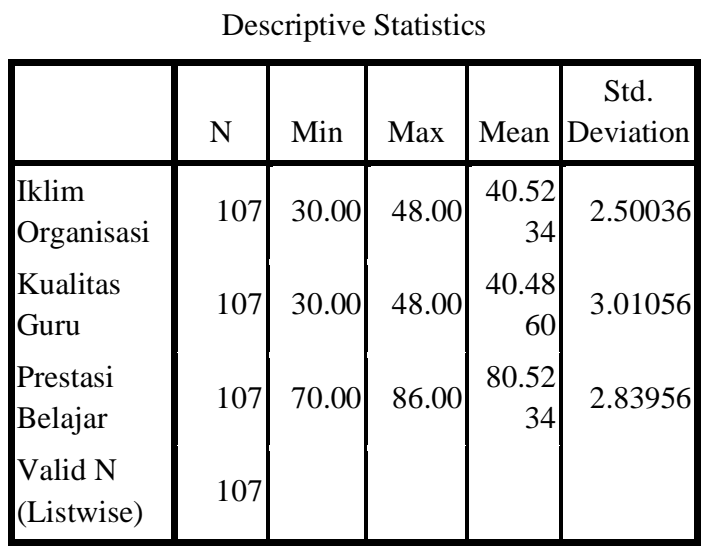

Dari tabel 1 deskriptif di atas menunjukan bahwa variabel terikat $\mathrm{Y}$ prestasi belajar siswa dengan nilai mean 80.5234 dan standar deviasi 2.83956 dengan jumlah data sampel penelitian 107. Sedangkan variabel pertama iklim organisasi dengan nilai mean 40.5234 dan standar deviasi 2.50036 dan variabel X2 kualitas mengajar guru dengan nilai mean 40.4860 dan standar deviasi 3.01056. Standar deviasi yang digunakan sebagai pembanding jika standar deviasi > dari standar error maka variabel bebas tidak baik untuk memprediksi variabel terikat. 
1332 Pengaruh Iklim Kerja dan Kualitas Mengajar Guru Terhadap Prestasi Belajar Siswa - Kristianus J. Tute, Lely Suryani, Ariswan Usman AJe

DOI: https://doi.org/10.31004/basicedu.v4i4.554

Dari tabel standar deviasi di atas

Dari tabel 3 diatas model summary regresi menunjukan variabel bebas mempengaruhi variabel terikat cukup baik karena nilai standar error lebih besar dari standar deviasi dengan skor maksimal masing-masing variabel yaitu variabel terikat 86, variabel bebas X1 dan X2 sebasar 70 . Dalam hal ini berarti variabel X1 dan X2 terhadap Y berada dalam level sedang.

Tabel 2 Korelasi Antar Variabel

\begin{tabular}{|ll|r|r|r|}
\hline & \multicolumn{1}{c|}{ Correlations } \\
\hline & & \multicolumn{1}{c|}{ PB } & \multicolumn{1}{c|}{ IO } & \multicolumn{1}{c|}{ KG } \\
\hline Pearson & PB & 1.000 & .754 & .774 \\
Correlation & IO & .754 & 1.000 & .702 \\
& KG & .774 & .702 & 1.000 \\
\hline Sig. (1-tailed) & PB &. & .000 & .000 \\
& IO & .000 &. & .000 \\
& KG & .000 & .000 & \\
\hline$N$ & PB & 107 & 107 & 107 \\
& IO & 107 & 107 & 107 \\
& KG & 107 & 107 & 107 \\
\hline
\end{tabular}

Tabel 2 menghasilkan korelasi antar variabel, dimana iklim kerja organisasi sekolah berkorelasi dengan prestasi belajar 0.754 ( $75.4 \%)$, dengan kualitas mengajar guru 0.702 ( $70.2 \%$ ). Dan korelasi antara kualitas mengajar guru dengan prestasi belajar siswa sebesar 0.774 ( 77.4 $\%)$. Dari tabel di atas korelasi bersifat signifikan .

Tabel 3. Model Summary Regresi Berganda

\begin{tabular}{|c|c|c|c|c|}
\hline \multicolumn{5}{|c|}{ Model Summary } \\
\hline Model & $R$ & $\begin{array}{c}R \\
\text { Square }\end{array}$ & $\begin{array}{c}\text { Adjusted } R \\
\text { Square }\end{array}$ & $\begin{array}{c}\text { Std. Error of } \\
\text { the Estimate }\end{array}$ \\
\hline 1 & $.829^{\mathrm{a}}$ & .687 & .681 & .39870 \\
\hline
\end{tabular}

a. Predictors: (Constant), $K G, I O$

b. Dependent Variable: $P B$

berganda variabel bebas secara simultan berpengaruh terhadap prestasi belajar (Y). Nilai $\mathrm{R}$ dengan derajat ketepatan variabel X1 dan X2 memprediksi variabel Y. Nilai R 0.829( 82.9\%) termasuk dalam kategori baik. $R$ squared dengan nilai kontribusi variabel independent secara simultan mempengaruhi variabel dependen sebesar 0.681 ( $68.1 \%$ ). Artinya sebesar 0.681 ( $68.1 \%$ ) Prestasi belajar siswa di Kecamatan Ende Utara dipengaruhi secara bersama-sama dengan variabel iklim organisasi sekolah dan kualitas mengajar guru. Sisanya $31.9 \%$ dipengaruhi oleh variabel yang lain, yang bukan menjadi fokus dalam penelitian ini.

Tabel 4. Anova

\begin{tabular}{|l|r|r|r|r|r|}
\hline Model & $\begin{array}{l}\text { Sum of } \\
\text { Squares }\end{array}$ & $d f$ & $\begin{array}{c}\text { Mean } \\
\text { Square }\end{array}$ & $F$ & Sig. \\
\hline $\begin{array}{l}\text { Regres } \\
\text { sion }\end{array}$ & 36.322 & 2 & 18.161 & 114.2 & $.000^{\mathrm{a}}$ \\
$\quad \begin{array}{l}\text { Residu } \\
\text { al }\end{array}$ & 16.532 & 104 & .159 & & \\
$\quad$ Total & 52.854 & 106 & & & \\
\hline
\end{tabular}
a. Predictors:
(Constant), $K G, I O$
b. Dependent
Variable: $P B$

Dari tabel 4 diatas menghasilkan analisis varian regresi ganda dengan nilai F 114.244 dengan derajat kebebasan sebesar 104 untuk menguji apakah kedua variabel bebas tersebut berpengaruh secara simultan terhadap variabel bebas atau tidak. Untuk melihat pengaruhnya atau tidak kita bisa melihat nilai $\mathrm{F}$ hitung di bandingan dengan $\mathrm{F}$ tabel dengan membandingkan nilai signifikan dengan parameter penelitian 114.244 
1333 Pengaruh Iklim Kerja dan Kualitas Mengajar Guru Terhadap Prestasi Belajar Siswa - Kristianus J. Tute, Lely Suryani, Ariswan Usman AJe

DOI: https://doi.org/10.31004/basicedu.v4i4.554

$>3.08$ dari $F$ tabel dengan nilai Sig. $0.000<0.05$ menolak $\mathrm{H}_{0}$. Artinya variabel $\mathrm{X} 1$ dan $\mathrm{X} 2$ berpengaruh terhadap Y secara bersama-sama.

Tabel 5 Coefficient Regresi Ganda

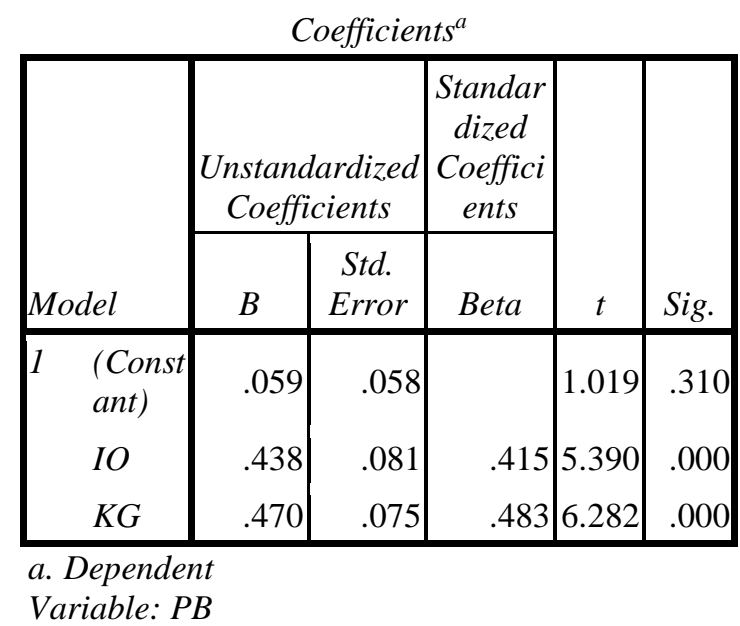

Dari tabel 5 menunjukan koefisien korelasi dari variabel bebas secara terpisah dengan variabel terikat dan dengan nilai t_hitung dan juga nilai signifikan dapat disimpulkan bahwa iklim organisasi sekolah 5.390> 3.08 ( t_tabel) dengan nilai sig. $0.000<0.05$ maka menolak $\mathrm{H}_{0}$, artinya variabel X1 berpengaruh terhadap Y. Kualitas mengajar guru berpengaruh terhadap prestasi belajar siswa dengan nilai $6.282>3.08$ dengan nilai Sig. $0.000<0.05$. Maka menolak $\mathrm{H}_{0}$ artinya variabel $\mathrm{X} 2$ berpengaruh terhadap Y.

Dari hasil uji model regresi dapat di simpulkan berdasarkan tabel diatas

1. Pada model korelasi, variabel iklim kerja (X1) menunjukan korelasi yang sangat signifikan dengan variabel kualitas mengajar guru (X2) terhadap prestasi belajar dengan korelasi X1 dan X2 0.702 ( 70.2\%). Dengan kategori nilai $0.000<0.05$. Maka menolak $\mathrm{H}_{0}$.
Variabel X1 iklim kerja sekolah terhadap Y sebasar 0.754(75.4\%). Variabel X2 berkorelasi dengan $\mathrm{Y}$ sebesar $0.774 \quad(77.4 \%)$ dengan kategori yang sangat signifikan dengan nilai signifikan $0.000<0.05$.

2. Model regresi berganda antara variabel X1 dan X2 menghasilkan koefisien korelasi secara bersama-sama terhadap Y sebesar 0.681 ( 68.1 $\%$ ) terhadap variabel Y prestasi belajar dengan nilai $F$ sebesar 114.244 dengan nilai signifikan $0.000<0.05$.

\section{Pengaruh iklim kerja dan kualitas mengajar guru secara bersama-sama terhadap prestasi belajar siswa}

Secara bersama-sama variabel X1 dan X2 menunjukan koefisien korelasi sebesar 0.681 terhadap variabel Y. Koefisien korelasi tersebut sangat signifikan karena nilai $\mathrm{F}$ yang dihasilkan 114.244 dengan nilai sig. $0.000<0.05$. Dari angka tersebut di atas menunjukan bahwa prestasi belajar siswa di sekolah sangat dipengaruhi oleh iklim kerja dan kualitas mengajar guru (kompetensi guru) secara bersama-sama sebesar 0.681 (68.1\%). Sisanya $31.9 \%$ yang bukan menjadi fokus dalam penelitian ini. Riset ini menunjukan bahwa jika iklim organisasi baik dan kualitas mengajar guru baik maka prestasi belajar baik begitu sebaliknya.

Hasil penelitian yang relevan dengan penelitian sebelumnya yaitu hasil penelitian Ideswal, Yahya, \& Alkadri, (2020) menyatakan bahwa jika iklim kerja sekolah baik dan kinerja mengajar guru baik maka mutu belajar siswa baik. 
1334 Pengaruh Iklim Kerja dan Kualitas Mengajar Guru Terhadap Prestasi Belajar Siswa - Kristianus J. Tute, Lely Suryani, Ariswan Usman AJe

DOI: https://doi.org/10.31004/basicedu.v4i4.554

\section{Pengaruh iklim kerja dan kualitas mengajar} guru secara terpisah terhadap prestasi belajar

Dari tabel korelasi pearson menghasilkan derajat korelasi $\mathrm{X} 1$ dan $\mathrm{X} 1$ secara parsial dengan variabel Y sebagai berikut: $\mathrm{X} 1$ terhadap $\mathrm{Y}=0.754$ ( $75.4 \%$ ). X2 terhadap $\mathrm{Y}=0.774(77.4 \%)$, kedua korelasi tersebut bersifat signifikan karena lebih kecil dari 0.05 . Yaitu $\mathrm{X} 1=0.000$ untuk dan $\mathrm{X} 2=0.000<0.05$.

Variabel $\mathrm{X} 1$ terhadap $\mathrm{Y}=$ dengan nilai beta 0.415 dan $\mathrm{X} 2=0.483$. Artinya secara terpisah kedua variabel tersebut berpengaruh terhadap prestasi belajar sebesar $41.5 \%$ dan $48.3 \%$. Penelitian ini juga mengacu pada penelitian Mirzon Daheri, Juliana, Deriwanto, (2020) kualitas atau kompetensi guru secara parsial berpengaruh secara positif terhadap hasil belajar. Artinya secara terpisah iklim organisasi mempengaruhi terhadap prestasi belajar sebesar $41.5 \%$, sisanya di pengaruhi oleh variabel lain yang bukan menjadi fokus dalam penelitian ini. Jika kualitas guru baik maka prestasi belajar juga baik.

\section{SIMPULAN}

Dari hasil analisis data dan pengujian hipotesis dalam penelitian ini dapat disimpulkan bahwa :

1. Iklim kerja sangat berpengaruh secara signifikan terhadap prestasi belajar siswa di Kecamatan Ende Utara, Kabupaten Ende.

2. Kualitas mengajar guru sangat berpengaruh secara positif terhadap prestasi belajar siswa di Kecamatan Ende Utara, Kabupaten Ende.

3. Iklim kerja sekolah dan kualitas mengajar guru berpengaruh secara positif secara bersamasama terhadap prestasi belajar siswa di Kecamatan Ende Utara, Kabupaten Ende.

\section{UCAPAN TERIMA KASIH}

Ucapan terima kasih kepada RISTEKDIKTI yang telah memberikan hibah penelitian kepada Tim Peneliti, Kepala LLPM Universitas Flores dan SMU Negeri 2 Ende, SMU Muhamadyah Ende, SMU Frareran Ndao Ende dan SMA Yos Sudarmo yang menjadi sampel penelitian.

\section{DAFTAR PUSTAKA}

Adib, F., \& Santoso, B. (2016). Upaya Penigkatan Prestasi Belajar Siswa Dengan Disiplin Kerja Guru. Jurnal Pendidikan Manajemen Perkantoran, $\quad 1(1), \quad 198$. https://doi.org/10.17509/jpm.v1i1.3388

Depdiknas. (2007). Depdiknas. In Depdiknas (Vol. 67). Jakarta: Depdiknas.

Dimyati, \& Mudjiono. (2006). Belajar dan Pembelajaran. Jakarta: Rineka Cipta.

Djamarah, Syaiful, B., \& Aswan, Z. (2012). Strategi Belajar Mengajar. Jakarta: Rineka Cipta.

Ideswal, I., Yahya, Y., \& Alkadri, H. (2020). Kontribusi Iklim Sekolah dan Kepemimpinan Kepala Sekolah terhadap Kinerja Guru Sekolah Dasar. Jurnal Basicedu, 4(2), 460466.

https://doi.org/10.31004/basicedu.v4i2.381

Karwati dan Priansa. (2014). Manajemen Kelas. Bandung: Alpfabeta.

Maria, \& Ungin. (2013). Studi tentang Kualitas Tenaga Pengajar (Guru) pada SMPN 17 Sendawar Kabupaten Kutai Barat. Jurnal Administrasi Negara, 1(1), 97-108.

Mirzon Daheri, Juliana, Deriwanto, A. D. A. (2020). Jurnal basicedu. Jurnal Basicedu, $3(2)$,

524-532. https://doi.org/10.31004/basicedu.v4i4.445

Muhibbin, S. (2003). Psikologi Pendidikan dengan Pendekatan Baru. Bandung: Remaja Rosdakarya. 
1335 Pengaruh Iklim Kerja dan Kualitas Mengajar Guru Terhadap Prestasi Belajar Siswa - Kristianus J. Tute, Lely Suryani, Ariswan Usman AJe

DOI: https://doi.org/10.31004/basicedu.v4i4.554

Omar, hamalik. (2013). Proses Belajar Mengajar. Jakarta: Bumi Aksara.

Oteng, S. (2009). Administrasi Pendidikan: Dasar teoritis Untuk Praktek Profesional. Bandung: Angkasa.

Raharjo, S. B. (2013). Evaluasi Trend Kualitas Pendidikan Di Indonesia. Jurnal Penelitian Dan Evaluasi Pendidikan, 16(2), 511-532. https://doi.org/10.21831/pep.v16i2.1129

Sanjaya, W. (2014). Perencanaan dan Desain Sistem Pembelajaran. Jakarta: Kencana Prenada Media Grup.

Supardi. (2013). Aplikasi Statistika dalam Penelitian Konsep Statistika yang Lebih Komprehensif. Jakarta: Change Publication.

Susanto, A. (2016). Teori Belajar dan Pembelajaran di SD. Yogyakarta: Pararaton ( Group Elmatera).

Wirawan. (2007). Budaya dan Iklim Organisasi Teori Aplikasi dan Penelitian. Jakarta: Salemba Empat. 